\title{
iPad at School: A Holistic Evaluation of the Opinions of Students, Teachers and Parents Concerning iPad Usage
}

\author{
Ahmet A $\breve{g} 1 r^{1, *}$ \\ ${ }^{1}$ Hasan Ali Yücel Education Faculty, Computer Education and Instructional Technology \\ Department, Istanbul University, Istanbul, Turkey \\ * Correspondence: İstanbul Üniversitesi Hasan Ali Yücel Eğitim Fakültesi, Vefa, Fatih, \\ İstanbul, Türkiye. Tel: 90-212-440-0047. E-mail: agir@istanbul.edu.tr
}

Received: June 29, 2015 Accepted: September 4, 2015 Published: September 25, 2015

doi:10.5296/ije.v7i3.7924 URL: http://dx.doi.org/10.5296/ije.v7i3.7924

\begin{abstract}
The present study contains data collected via end of the year assessments concerning iPad applications created especially for primary schools, and includes analyses of the data. To integrate smart board usage in primary school lessons, various applications were developed to ensure the synchronization of the smart boards and iPads. These applications were used by both students and teachers in class sessions throughout the academic year. At the end of the academic year, the usage of the iPad in the classes, the effects of iPad on class activities and teaching methods; and the opinions of the students, teachers and parents on iPad usage at academics in an educational context were sought and evaluated.
\end{abstract}

Keywords: iPad, teacher opinions, mobile learning. 


\section{Introduction}

Information technologies affect teaching and learning methods deeply as well as every other part of our daily life. There is an expectation that educational systems should be open, and capable of integrating new technologies in their work to a reasonable extent. The tools that are being used in lessons increase student motivation and their willingness to participate in class, and such tools help them to learn more effectively.

As technology becomes intertwined in our lives and with the birth of digital natives, schools are attempting to utilize technology to help provide the best learning experience for children. Traditionally, the use of Information and Communications Technology (ICT) in education has been segregated from the normal teaching classroom: personal computers were relegated to a separate computer lab where students would go to study computer-related topics. A more technology integrated classroom might have a PC or two down the back of the room that students could sometimes use during class time. More recently, smaller devices such as laptops, tablets and mobile devices have been tested and used within the classroom as a tool to help children supplement their lessons. These changes mean there is need to investigate the impact these modern educational devices have in the classroom and on childhood education (Henderson \&Yeow, 2012).

With the assistance of modern teaching methods, different research studies are being conducted in schools to encourage students to find a new vision of learning.

The use of smart boards and tablet computers in schools became part of daily life. In its report, Becta (2004) stated that the day to day usage of tablet computers in the academic field had become more popular. Tablet computers are a new subdivision of computers and more convenient for students and teachers alike (Gill, 2007). Tablet computers are suitable for checking and reading content, surfing the net, drawing with a finger, or main activities such as writing and drawing thanks to the multi-touch screen (Galligan, Loch, Mcdonald \& Taylor, 2010).

Some private schools in Istanbul, Turkey tried to adopt the technology. One of the first private secondary schools' 6th and 7th grades students purchased iPads for classroom usage in 2010-2011 educational term.

This paper will explore the first experience of that private primary school in Turkey they adopted the iPad for using in classroom with 6th and 7th grades students. We seek to understand the issues the school and students experienced and the thoughts of they perceived from both educational and personal perspectives.

\section{Literature Review}

This section will briefly review some researches and implementation of tablet usage in schools.

Valstad (2011) highlights on the effect the introduction of iPad created in Norwegian school. 
The excitement by the student triggered a much time spent on reading using the device. The devices made learning fun and more attractive to the students. Teachers were initially apprehensive but later embraced the technology.

This thesis studies the use of iPad in a Norwegian classroom. The aim of this thesis is to evaluate how suitable the iPad is in a classroom, what are the advantages and disadvantages of using it and if it can produce increased motivation towards learning among students. To conduct this evaluation in a realistic setting, a class with 15 students together with 5 teachers were each provided with $1 \mathrm{iPad}$. A set of qualitative data gathering activities were selected; observations, focus group meetings and interviews. Through these activities empirical data was obtained for further analysis and discussion.

The proliferation of mobile technology provides a myriad of opportunities to support learning and performance both inside and outside the classroom. Mobile technology opens the door for a new kind of learning and performance support in the field, providing anytime and anywhere access to information, processes, and communication (Martin, \& Ertzberger, 2013).

One iPad educational implementation project that involved students and professors (2011) suggests that iPads are impacting specific educational practices. They indicate that early assessments of the institution-wide use of iPads in a college points to faculty using the devices for three main categories of activities. These activities are: immediate $\&$ authentic information gathering, instruction \& reinforcement, and Instructional \& student presentations. Further findings also identify that iPads are being used by students for real time backchannel discussions during class time, as clicker response devices, and for using and searching e-textbooks. There are also reports that faculty and students both use the iPad devices for convenience, portability, communication, information gathering, note taking, reading, and interactive work (Gawelek, Spataro \& Komarny, 2011).

Henderson \& Yeow (2012) explore the experience of that New Zealand primary school as they adopted the iPad for use in the classroom with students aged $5-12$. They seek to understand the issues they faced and the benefits they perceived from both educational and IT management perspectives (Henderson and Yeow, 2012).

Firstly they presented background information on the school regarding their selection of the iPad, followed by the management or administrative perspective on the iPad. Finally, they explored how the iPad is used in the classroom and the surrounding issues teachers have encountered (Henderson \&Yeow, 2012).

Roslyn High School has implemented an iPad project by issuing 47 iPads to two humanity classes. The program aimed to replace the cost of purchasing textbooks since the iPads supported the use of textbooks in soft copies. Further, the program aimed to ensure that all the 1100 students in the school could use an iPad by the end of the program implementation. Teachers in the school cited the benefits of an effective implementation which included a wider way to view education issues, termed as thinking beyond the four classroom walls. According to $\mathrm{Hu}$ (2011), technology implementations in schools have unfolded in the past. She says that technological adoption including video games, and You Tube were successfully 
implemented, although they may not have achieved the required results. She also says that it is hard to measure the effect of the program which involved issuing of laptops to every student (Hu, 2011).

The findings indicate that the iPad hold many advantages in a classroom, but not without disadvantages. iPad's convenient size made reading easier for the students. Multiple means of content representation and possible ways of expression provided students with options in learning. It was found an increase in motivation among several of the students. The disadvantages are that the iPad requires extensive training, if it would be used to it fullest potential and not as another substitute to a laptop computer. Lack of educational content, such as multimedia enriched books are needed to increase learning, because PDF versions of text-books does not introduce anything new except increased portability (Valstad,2011).

An and Alon's (2013) case study examined existing iPad logistical models in NJ public school classrooms. It is anticipated that these findings will help to inform school district planning and logistical concerns, as well as to examine the students' and teachers' perceived attitudes and beliefs about using iPads in their classrooms (An,. \& Alon,2013).

Clarke and Svanaes's (2012) research report on the feasibility of the secondary schools one-to-one tablets. The report summarizes the report findings for three secondary schools that had chosen to give pupils one-to-one tablets and which have implemented the program. It includes a literature review of the global studies on the issue. It was carried out between September 2011 and July 2012. It identifies the stages of program implementation impact of the program and the challenges.

Results suggest several benefits to learning including an increased motivation to learn; increased parental engagement; more efficient monitoring of progress between pupil and teacher; greater collaboration between teacher and pupil and between pupil and pupil. It appears that one-to-one Tablets offer a sense of inclusion that allow children, irrespective of socio-economic status or level of attainment, an opportunity to thrive through a new pedagogical model of pupil-led learning (Clarke \& Svanaes, 2012).

Jones (2012) article is focusing on the reports on the implementation program for the tablet computers at Cherry Valley in the Cross County School District. The school uses the ipads which are transported to every class using the apple lab (Jones,2012).

Bounds (2013) discusses the adoption of ipads with the aim of improving the learning outcome. The article highlights the basic requirements for successful program implementation which include, teacher training, security and wireless band width expansion Bounds, 2013).

One-to-One Computers in Schools Review is a literature review focusing on research and other articles dealing with the subject of technology adoption in schools. It review the advantages of providing each student with a computer aimed at improving learning in the schools (One-to-One Computers in Schools, 2010). 


\section{Method}

\subsection{Model of Research}

In the present research, a scanning model of descriptive research method was used for put forth their views of teachers and parents about iPad usage. The screening method research approach aims to describe a situation existed in the past or continues in the present. Events that are the subject of the research will be attempted. It has not effort to make to impress them in any way modify or affect. The important thing is to identify the research subject, observing it in an appropriate manner (Karasar, 2008).

In the present study, conducted in a private school, which for research will be carried a smart board, a Mac mini, and an iPad, for which applications have been developed to enable them to work together. In all classes, students and teachers usage of the devices and applications was actively monitored throughout the year. In the courses, all the visual and digital content on the course topics was built in to send out to the teachers' Mac mini, which is connected with smart boards, and students' iPads. Students also had access to the course content, they hold notes in any time and accessed to course notes by using this software,. The providing of audio and visual interactive content accelerates the learning process. In addition, with the tablets running and integrated with smart board lessons, more interactive processing is provided. Throughout the research process students learn how to process the course with the iPad and Mac mini, all notes, assignments and curriculum were followed in the digital environment and they were able to move as they wished. After a year of research the data collection process was begun.

During the research, the aim of which was to provide a guide to schools planning to or beginning to use these new techniques and to find good applications for tablet computers and deepen the application sharing experience between the students, descriptive methods were used to uncover an existing situation.

As part of the research, various applications were developed to ensure the synchronization of smart board and iPads. Students and teachers used the applications in their lessons throughout the academic year. It's been proposed that during lessons, teachers send all of their visual and audial contents from their smart board connected Mac mini to their iPads equipped with iPad software. Furthermore, it was arranged that besides using this software to access lesson materials anytime, students could also access the notes they had taken as well. Audial and visual materials also speed up the learning process and contain a versatile teaching material pool including videos, photographs and writings to increase the quality of it. Furthermore, by using tablet computers and integrating them in to smart board, it has been observed that students participate lessons more interactively. During the research period, students used their iPads and Mac mini in class and were able to follow all the notes, homework and the curriculum on the digital platform. In the 2011-2012 academic year, every student in (the primary) $6^{\text {th }}$ and $7^{\text {th }}$ grade used a tablet at the private school.

\subsection{Work Group}

For the assessments of students and teachers all the $6^{\text {th }}$ and $7^{\text {th }}$ grade students were picked by 
purposeful sampling; also all tablet using students were included in the present research. The reason for this is that the school where the research was conducted was the only school that uses tablets. Furthermore, these students' parents and teachers were picked by simple sampling methods. With 94 from the $6^{\text {th }}$ grade and 51 from the $7^{\text {th }}$ grade, a total of 145 students participated in this research. 35 parents participated in the research, and 18 teachers were included.

Table 1. Number of Students by Grade

\begin{tabular}{cc}
\hline Grade & Number of Students \\
\hline $\mathbf{6}$ & 94 \\
7 & 51 \\
Total & 145 \\
\hline
\end{tabular}

The number of students is presented in Table 1 according to their classes. Ninety four of them are 6 th grade students; 51 of them are 7 th grade students. The total number of student participants is 145 .

Table 2. Number of Teachers by Grade

\begin{tabular}{ll}
\hline (1) Grade & (2) Number of Teachers \\
\hline (3) 6 & (4) 10 \\
(5) 7 & (6) 8 \\
(7) Total & (8) 18 \\
\hline
\end{tabular}

The number of teachers is presented in Table 2 according to their Grade. Ten of them are 6th grade students; eight of them are 7 th grade students. The total number of teacher participants is 18 .

Table 3. Number of Parents by Grade

\begin{tabular}{lc}
\hline (9) Grade & (10) Number of Parents \\
\hline (11) 6 & $(12) 20$ \\
(13) 7 & $(14) 15$ \\
(15) Total : & $(16) 35$ \\
\hline
\end{tabular}

The number of parents is presented in Table 3 according to their Grade. Twenty of them are 6 th grade students; fifteen of them are 7 th grade students. The total number of teacher participants is 35 .

\subsection{Data Collecting Tools}

The data collecting tools are surveys prepared for the student, teacher and parents. The surveys given to students mainly consist of questions on the usage of iPad for educational purposes; their opinions about the benefits of iPad, how satisfied they are about the quality of the educational materials on the tablets. The surveys given to teachers mainly focus on their 
opinions concerning student activities, teacher and student questions about and opinions concerning iPad usage. In the parent surveys questions are asked concerning their views on learning via tablets, and the usage hours for iPad.

The surveys were copied and deployed in the school by the researcher. Researchers made the surveys in the school. Participants were selected by a simple random sampling method. Surveys was applied to students and teachers. In the simple random sampling method, the sample size is determined by the researcher in order to select a part of the universe (Arl1 \& Nazik, 2001). The school administrators were informed about the research, and the necessary permission was sought and taken. Brief description, such as general purpose of survey and the questions related to the data collection tools were given to the participants. In addition, the questions of the parents about the survey were answered. Emphasized the names of the parents will be kept anonymous. The results would be evaluated collectively rather than individually.

\section{Findıngs and Remarks}

\subsection{Assessment of Student Survey}

Table 4. Number use of the iPad According to personal usage

\begin{tabular}{|c|c|c|c|c|c|}
\hline (17) & $\begin{array}{l}\text { (18)(1) } \\
\text { Never }\end{array}$ & $\begin{array}{c}(19)(2) \\
\text { Few }\end{array}$ & $\begin{array}{c}(20)(3) \\
\text { Sometimes }\end{array}$ & $\begin{array}{c}(21)(4) \\
\text { Frequently }\end{array}$ & $\begin{array}{l}\text { (22)(5) } \\
\text { Always }\end{array}$ \\
\hline (23) Communication with classmate & $(24) 18$ & $(25) 18$ & (26) 27 & $(27) 24$ & (28) 58 \\
\hline (29) Watching video & (30) 18 & (31) 15 & (32) 26 & (33) 33 & (34) 53 \\
\hline (35) Playing games & (36) 14 & (37) 16 & (38) 38 & (39) 29 & (40) 48 \\
\hline (41) Listening to music & (42) 14 & (43) 9 & (44) 19 & (45) 33 & (46) 70 \\
\hline (47) Reading journals & (48) 38 & (49) 24 & (50) 20 & (51) 16 & $(52) 47$ \\
\hline (53) Reading newspapers & $(54) 48$ & $(55) 27$ & $(56) 23$ & $(57) 24$ & (58) 23 \\
\hline $\begin{array}{l}\text { (59) Communication with friends } \\
\text { (Facebook, Twitter, Skype, email, } \\
\text { chat) }\end{array}$ & $(60) 20$ & $(61) 5$ & (62) 15 & (63) 22 & (64) 83 \\
\hline
\end{tabular}

As can be seen from Table 4, approximately three quarters of students (72\%) frequently and always use iPad to communicate with their friends. Similarly approximately three quarters of students (71\%) frequently and always use iPad listen to music, Social tools such as Facebook are considered to be the most commonly used applications. Half of students $(52 \%)$ never or few use iPad to read newspapers. 
Table 5. Number of the use of iPad as for educational usage

\begin{tabular}{lccccc}
\hline & (1) Never & (2) Few & (3) Sometimes & (4) Frequently & (5) Always \\
\hline Conduct research & 8 & 14 & 45 & 49 & 29 \\
Doing homework & 11 & 18 & 40 & 41 & 35 \\
Looking through E-books & 44 & 32 & 46 & 11 & 12 \\
Making presentations & 34 & 23 & 34 & 41 & 13 \\
Communications with the teacher & 47 & 18 & 20 & 29 & 31 \\
Solving exercise questions & 38 & 22 & 36 & 33 & 16 \\
Taking an examination & 55 & 22 & 30 & 16 & 22 \\
Taking a test & 39 & 26 & 38 & 21 & 21 \\
\hline
\end{tabular}

As can be seen from Table 5, half of the students (54\%) frequently and always use iPad to conduct research and similarly half of the students (52\%) frequently and always use iPad to doing homework. Very few students (\%16) reads frequently and always use ipad for reading e-books By assuming the amount of presentation, project work and homework given to the students it is legitimate to say that these statistics reflect the truth.

It can be observed that students do not use the iPad to read e-books. These results might have occurred because students couldn't find any e-books to read, they don't like to read books on virtual databases, or they want to focus on interactive sources. Similarly, students do not prefer to use the iPad for making presentations. Approximately half of the students (44\%) are using never or few the iPad to communicate with their teachers.

Table 6. Number of Satisfaction - Benefit Status on Student's iPad Usage for the Purpose of Education

\begin{tabular}{llllll}
\hline & $\begin{array}{l}\text { (1) } \\
\text { Strongly } \\
\text { Disagree }\end{array}$ & $\begin{array}{l}\text { (2) } \\
\text { Disagree }\end{array}$ & $\begin{array}{l}\text { (3) } \\
\text { No Opinion }\end{array}$ & $\begin{array}{l}\text { (4) } \\
\text { Agree }\end{array}$ & $\begin{array}{l}\text { (5) } \\
\text { Strongly Agree }\end{array}$ \\
\hline $\begin{array}{l}\text { Using the iPad on the course } \\
\text { facilitated my learning. }\end{array}$ & 10 & 7 & 39 & 39 & 50 \\
$\begin{array}{l}\text { Using the iPad on the course } \\
\text { provided me to perform more } \\
\text { easily and do my homework } \\
\text { and projects. }\end{array}$ & 11 & 16 & 20 & 38 & 60 \\
$\begin{array}{l}\text { I've enjoyed using the iPad on } \\
\text { the course. }\end{array}$ & 10 & 6 & 16 & 35 & 78 \\
$\begin{array}{l}\text { I would recommend that my } \\
\text { friends do their lessons using } \\
\text { iPad. }\end{array}$ & 7 & 12 & 27 & 38 & 61 \\
$\begin{array}{l}\text { Using the iPad, we are quickly } \\
\text { able to complete topics which } \\
\text { we need to proceed with our } \\
\text { course program }\end{array}$ & 10 & 8 & & & \\
\hline
\end{tabular}




\section{Macrothink Institute ${ }^{\text {TM }}$}

From Table 6 it is becomes clear that approximately three quarters of students (76\%) agree and strongly agree that using the iPad, students are quickly able to complete topics which they need to proceed with their course program. 98 of all students $(\% 68)$ say that using the iPad on the course provided me to perform more easily and do my homework and projects... Similarly, more than half of the students $(68 \%)$ agree and strongly agree to suggest their friends use iPad for their lessons. Generally, it would not be wrong to say that students are satisfied with using the iPad for educational purposes.

Table 7. Number of Educational Material Satisfaction Status on Student iPad Usage

\begin{tabular}{|c|c|c|c|c|c|}
\hline & $\begin{array}{l}\text { (1) } \\
\text { Strongly } \\
\text { Disagree }\end{array}$ & $\begin{array}{l}\text { (2) } \\
\text { Disagree }\end{array}$ & $\begin{array}{l}\text { (3) } \\
\text { No Opinion }\end{array}$ & $\begin{array}{l}\text { (4) } \\
\text { Agree }\end{array}$ & $\begin{array}{l}\text { (5) } \\
\text { Strongly } \\
\text { Agree }\end{array}$ \\
\hline Mostly the videos viewed during the & & & & & \\
\hline lessons attracted my attention. & 19 & 24 & 36 & 30 & 36 \\
\hline $\begin{array}{l}\text { Mostly I learned from the videos in the } \\
\text { lessons. }\end{array}$ & 26 & 20 & 39 & 34 & 26 \\
\hline Mostly the animations we watched in the & & & & & \\
\hline lessons attracted my attention. & 20 & 21 & 32 & 34 & 38 \\
\hline $\begin{array}{l}\text { Mostly I learned from the animations we } \\
\text { watched in the lessons }\end{array}$ & 21 & 21 & 38 & 34 & 31 \\
\hline $\begin{array}{l}\text { Mostly the tests solved during the lessons } \\
\text { attracted my attention. }\end{array}$ & 27 & 29 & 31 & 36 & 22 \\
\hline $\begin{array}{l}\text { Mostly I learned from the tests we solved } \\
\text { in the lessons. }\end{array}$ & 25 & 25 & 33 & 32 & 30 \\
\hline $\begin{array}{l}\text { Mostly interactive games played during } \\
\text { the lessons attracted my attention. }\end{array}$ & 25 & 17 & 31 & 32 & 40 \\
\hline $\begin{array}{l}\text { Mostly I learned from the interactive } \\
\text { games which we played in the lessons. }\end{array}$ & 21 & 22 & 27 & 29 & 46 \\
\hline $\begin{array}{l}\text { Mostly the presentations our teacher } \\
\text { showed during the lessons attracted my } \\
\text { attention. }\end{array}$ & 8 & 12 & 35 & 38 & 52 \\
\hline $\begin{array}{l}\text { Mostly I learned from the presentations } \\
\text { our teacher showed in the lessons. }\end{array}$ & 10 & 6 & 28 & 37 & 64 \\
\hline
\end{tabular}

It can be seen from Table 7 that approximately half of the students (46\%) strongly agree and agree that mostly the videos viewed during the lessons attracted their attention.., However compared to these results, very fewer students strongly agree and agree (41\%) that they learnt from videos shown in lessons. We can say that using video is attractive and help to learn to students when iPad used in the classroom. Similar results shown for the animations students watched in the lessons attracted their attention (50\%) and students learned from the animations they watched in the lessons (45\%). However for the $3^{\text {rd }}$ and $4^{\text {th }}$ groups of items tests solved in the classroom and games played during the lessons, a little more students thought learnt in the lessons. 


\section{Macrothink}

More than half of the students (62\%) agree and strongly agree that the presentations their teacher showed during the lessons attracted their attention. But in this case more students, approximately three quarters of students (70\%) agree and strongly agree that they learned from the presentations their teacher showed in the lessons. Teacher presentations are interesting and are helpful for learning. While using iPad in the classroom teacher presentations should be a suitable method to teach the more difficult subjects or any subject students do not like.

\subsection{Teacher Survey Assessment}

Table 8. The Opinions of Teachers about Student Activities

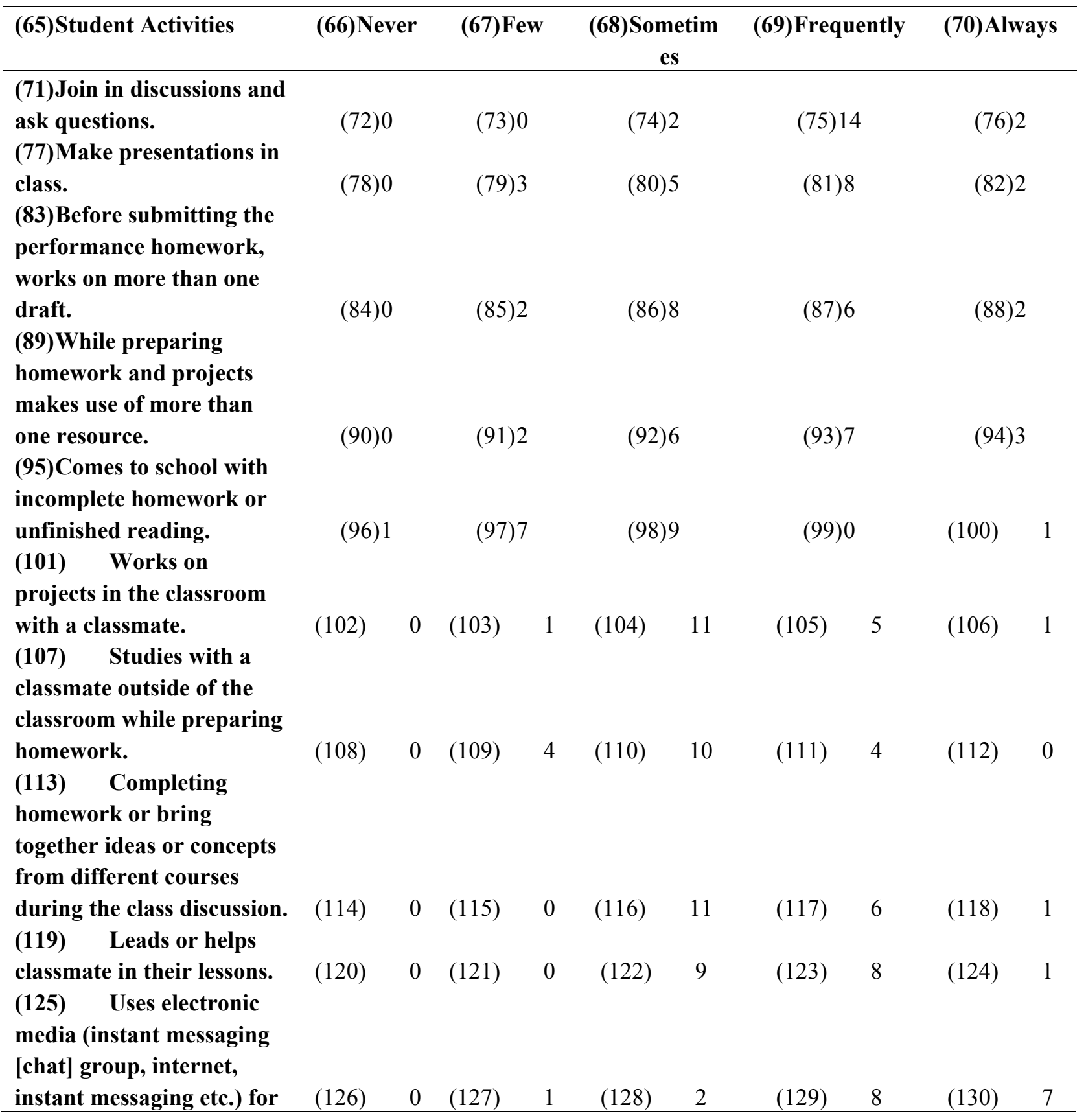


researching and doing homework.

(131) Uses e-mail for communication with the instructor.

(137) Talks about exam results or homework with the instructor.

$\begin{array}{lllllllll}0 & (133) & 2 & (134) & 8 & (135) & 4 & (136)\end{array}$

$\begin{array}{llllllllll}(138) & 0 & (139) & 2 & (140) & 5 & (141) & 5 & (142) & 6 \\ (144) & 0 & (145) & 1 & (146) & 6 & (147) & 7 & (148) & 4\end{array}$

(143) Talks with the instructor or counsellor about future plans.

(149) Discussions with the instructor outside of the class about information obtained and ideas formed from reading assignments or class.

$\begin{array}{llllllllll}(150) & 0 & (151) & 1 & (152) & 9 & (153) & 5 & \text { (154) } & 3\end{array}$

(155) Takes written or oral feedback from teachers on school performance.

(156)

(162) Studies more in

$\begin{array}{llllllllll}(157) & 0 & (158) & 0 & (159) & 3 & (160) & 10 & \text { (161) } & 5\end{array}$

order to meet the teachers' educational expectations.

(168) Works with teachers on extracurricular activities.

(169)

(175) Discusses with

$\begin{array}{lllllllll}0 & (164) & 2 & (165) & 6 & (166) & 9 & (167) & 1\end{array}$

others (students, family

members, acquaintances,

etc.) Information gained

and ideas formed from

reading assignments or

class outside of the class.

$\begin{array}{lllll}0 & (171) \quad 2 & (172) \quad 7\end{array}$

(173) 6

(174) 3

Most of the teachers state (89\%) that students frequently and always join in discussions and ask questions during class sessions. More than three quarters of teachers $(83 \%)$ say that students frequently and always "Uses electronic media (instant messaging [chat] group, internet, instant messaging etc.) for researching and doing homework" and "takes written or oral feedback from teachers on school performance". Students trying to receive feedback from their teachers and study according to their instructions.

Half of the teachers claims that students make many activities frequently and always in the classroom such as "Make presentations in class", "While preparing homework and projects makes use of more than one resource", "leads or helps classmate in their lessons", "talks about 
exam results or homework with the instructor", "talks with the instructor or counsellor about future plans", "studies more in order to meet the teachers' educational expectations", and "works with teachers on extracurricular activities". However one third of the teachers $(33 \%)$ state that students frequently and always "works on projects in the classroom with a classmate". Similarly teachers (39\%) state students frequently and always "discusses with others (students, family members, acquaintances, etc.) information gained and ideas formed from reading assignments or class outside of the class".

More than half of the teachers $(61 \%)$ claim that students sometimes "Works on projects in the classroom with a classmate", "Completing homework or bring together ideas or concepts from different courses during the class discussion", "Discusses with others (students, family members, acquaintances, etc.) Information gained and ideas formed from reading assignments or class outside of the class.". All these same data show that some collaborative activities of students are not usual in their classroom.

After these activities, it can be seen that students commit to "using different resources while preparing homework and projects" and "consulting teachers about their future".

Seeing these activities that students frequently accomplish, it became clear that all these things can be conducted easily with iPad. Online forums can be created for students who regularly ask questions and attend debates; students can communicate with their teachers or students from other schools with the help of various chat programs. Similarly, students can study more with different resources and materials with the iPad; for example teaching software, lecture presentations, materials that the teacher has established and e-books. Online assessment systems can be developed to give feedback to students or materials for them to use in their research projects. Furthermore, students can easily research their homework on the internet; take notes with iPad, and create a presentation. Counselling programs can be used by teachers to give a feedback.

Table 9. The Opinions of Teachers About iPad Usage of Students

\begin{tabular}{|c|c|c|c|c|c|}
\hline $\begin{array}{l}\text { (181) Please give your thoughts on iPad usage in } \\
\text { the classroom by the students. }\end{array}$ & $\begin{array}{l}\text { (182) Strongly } \\
\text { (183)Disagree }\end{array}$ & (184)Disagree & (185) No Opinion & (186) Agree & $\begin{array}{l}\text { (187) Strongly } \\
\text { (188) Agree }\end{array}$ \\
\hline \multicolumn{6}{|l|}{ (189)iPad usage supports learning -teaching } \\
\hline process. & $(190) 0$ & $(191) 2$ & $(192) 0$ & $(193) 9$ & $(194) 7$ \\
\hline $\begin{array}{l}\text { (195)iPad usage facilitates the task of teachers. } \\
\text { (201) Teachers can easily find materials which }\end{array}$ & $(196) 0$ & $(197) 0$ & $(198) 2$ & $(199) 5$ & (200) 11 \\
\hline $\begin{array}{l}\text { are compatible with iPad. } \\
\text { (202) }\end{array}$ & $(203) 1$ & $(204) 2$ & $(205) 1$ & $(206) 7$ & $(207) 7$ \\
\hline \multicolumn{6}{|l|}{$\begin{array}{l}\text { (208) The curriculum can be finished on time by } \\
\text { using iPad. }\end{array}$} \\
\hline (209) & $(210) 0$ & $(211) 0$ & $(212) 1$ & $(213) 3$ & (214) 14 \\
\hline \multicolumn{6}{|l|}{ (215)Current curriculum should be changed } \\
\hline \multicolumn{6}{|l|}{ for effective iPad usage. } \\
\hline \multicolumn{6}{|l|}{ (222)The required software and course } \\
\hline iPad usage, & $(223) 6$ & $(224) 1$ & $(225) 3$ & $(226) 5$ & $(227) 3$ \\
\hline
\end{tabular}




\section{Macrothink

It can be seen from the teachers' opinions about iPad usage, most of the teachers have positive thoughts. They are agree and strongly agree that ipad usage moderately supports the teaching-learning process (89\%), iPad makes their jobs easier $(89 \%)$.

Approximately three quarters of the teachers (78\%) agree and strongly agree that they can easily find proper material and programs suitable for iPad usage. and current curriculum should be changed for effective iPad usage. Less than half of the teachers (44\%) agree and strongly agree that for effective iPad usage, the required software and course materials are provided to teachers. Most of the teachers (94\%) think that the teaching curriculum can be completed by using iPads.

By looking at these results it would not be incorrect to say that iPad usage is found to be useful and efficient, thus making it acceptable to teachers. However, the teacher might insist that too much software should not be provided as they should have the opportunity to search for themselves. Some essential changes should be made in the curriculum for the iPad to be used to its fullest extent. The teachers claimed that insufficient lesson materials and not enough software provided for them,

\subsection{Parental Survey Assessments}

Table 10. iPad Usage and Learning Relationship

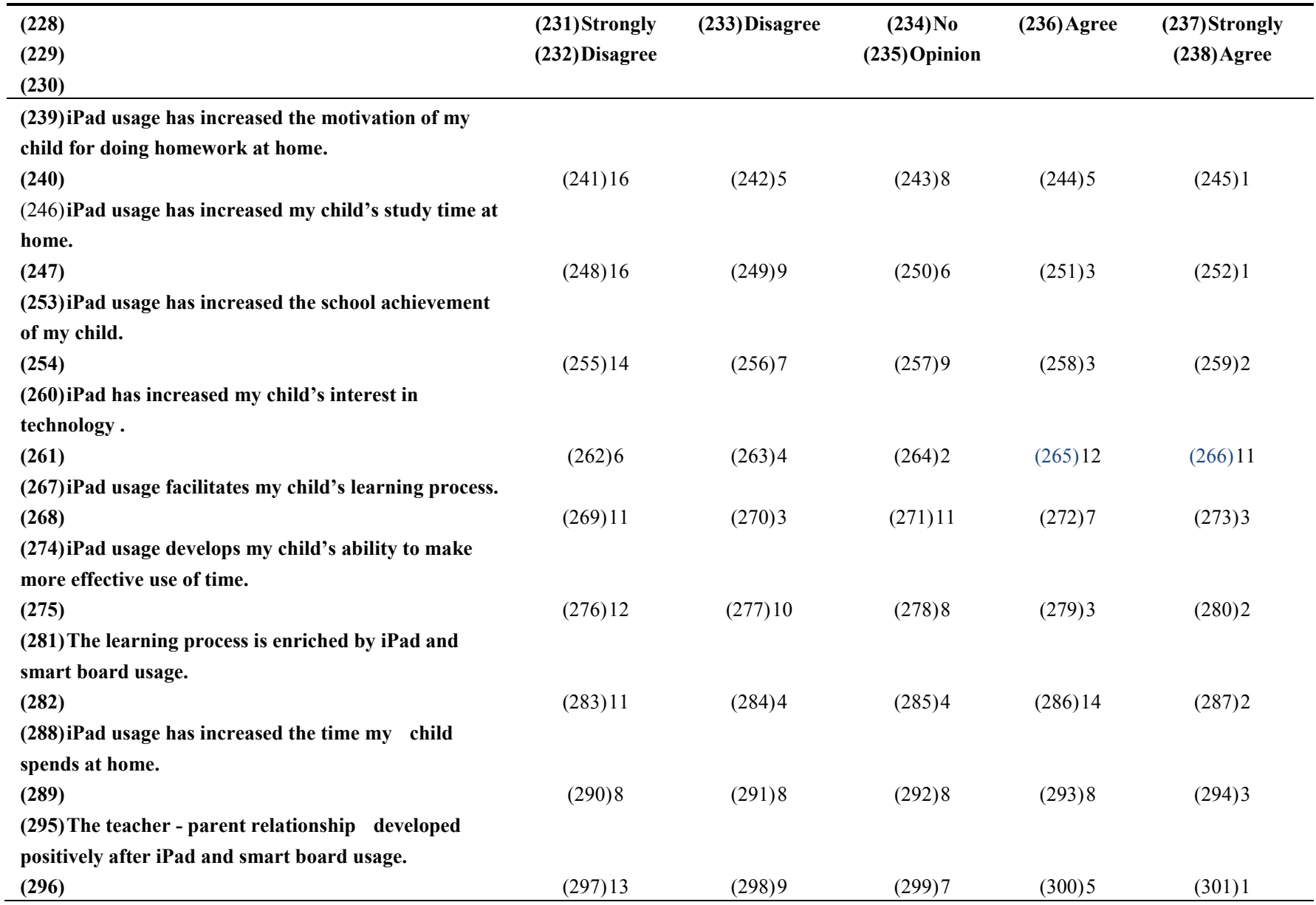


(302) The teacher - student cooperation became more effective after iPad and smart board usage. (303)

(309) The teacher - parent cooperation became more effective after iPad and smart board usage. (310)

(316) The teacher - student relationship developed
positively after iPad and smart board usage. (317)

(323)iPad usage has positively affected my child's friendship who classmates.

$$
\text { (324) }
$$

(330)iPad usage has reduced my child's interest in books .

(331)

(337)iPad usage has increased my child's sense of responsibility.

$$
\text { (338) }
$$

(344)iPad usage has reduced the burden of carrying books and notebooks to school.

$$
\text { (345) }
$$

(346) 12

(347) 8

(348) 4

(351) After using the iPad, we have reduced the time spent with my child.

$$
\text { (352) }
$$

(353) 5

(354) 10

(355) 2

(356) 10

(358)iPad usage has a negative impact on my child's handwriting skills.

(365)iPad usage has a negative impact on interaction with the family at home.

$$
\text { (366) }
$$

(372)iPad usage has created a technology addiction in my child.

(379)iPad usage has reduced my child's participation in family activities.

$$
\text { (380) }
$$

(381)6

(386)iPad usage prevents a social individual of my child.

(393)iPad usage has negatively affected my child's sporting activities.

(394)7

(395) 16

(396) 6

(397)2

(398) 4

(399)I could not control my child's use of the Internet with the iPad.

25 parents $(71 \%)$ state strongly disagree and disagree that "iPad usage has increased my child's study time at home. 24 parents (69\%) state strongly disagree and disagree that iPad usage has positively affected my child's friendship who classmates. 23 parents (66\%) state strongly disagree and disagree that iPad usage has negatively affected my child's sporting activities. 22 parents $(63 \%)$ state strongly disagree and disagree that "iPad usage develops my child's ability to make more effective use of time" and "The teacher - parent relationship developed positively after iPad and smart board usage".

21 parents (60\%) state strongly disagree and disagree for he following items 


\section{Macrothink Institute $^{\mathrm{TM}}$}

- "iPad usage has increased the motivation of my child for doing homework at home".

- "iPad usage has increased the school achievement of my child".

- "iPad usage has increased my child's sense of responsibility".

- "iPad usage prevents a social individual of my child".

- "The teacher - parent cooperation became more effective after iPad and smart board usage".

23 parents $(66 \%)$ state strongly agree and agree that "iPad usage has increased their child's interest in technology". 21 parents (60\%) state strongly agree and agree that "iPad usage has reduced their child's interest in books". 18 parents (51\%) state strongly agree and agree that "after using the iPad, they have reduced the time spent with their child" and "iPad usage has create a technology addiction in their child. Half of the parents (49\%) state strongly agree and agree that they could not control their child's use of the Internet with the iPad.

Approximately half the of the parents strongly disagree and disagree, other half of the parents strongly agree and agree for the following items.

- iPad usage has a negative impact on interaction with the family at home.

(Number of parents: $17-15$ ) (Percentage of parents: 49\%-43\%)

- iPad has reduced my child's participation in family activities.

(Number of parents: $17-14$ ) (Percentage of parents: 49\%-40\%)

- iPad has a negative impact on my child's handwriting skills.

(Number of parents: $16-14$ ) (Percentage of parents: 46\%-40\%)

- The learning process is enriched by iPad and smart board usage.

(Number of parents: $15-16$ ) (Percentage of parents: $43 \%-46 \%$ )

- I could not control my child's use of the Internet with the iPad.

(Number of parents: $15-17$ ) (Percentage of parents: 43\%-49\%)

- After using the iPad, we have reduced the time spent with my child.

(Number of parents: $15-18$ ) (Percentage of parents: 43\%-51\%)

Table 11. Parent views on their child's daily iPad usage time with the purpose of education and training.

(405)

$(406)$

Less $(407)$

1- $(408)$

2 (409)

(410) More

than 1 hour

2 hour

-3 hour

than 4 hours

(411) How many hours does your child use his/her iPad for teaching and learning?

(412)

(418)

How many hours your child using

(414)

$9 \quad(415)$

$4(416)$

(417)

5

his/her iPad for purposes other than teaching and

learning?

(419)

$9 \quad(420)$


Fourteen of the parents $(40 \%)$ state that their children use the iPad for no more than 1 hour for educational purposes; 9 of them (26\%) said the children spend 1-2 hours using iPad, 4 of them (11\%) said the children spend 2-3 hours using iPad, 3 of them (9\%) said the children spend 3-4 hours using iPad, and 5 of them (14\%) said the children spend more than 4 hours using iPad,

Nine of the the parents $(26 \%)$ state that their children use the iPad for no more than 1 hour for purposes other than teaching and learning; 10 of them (29\%) said the children spend 1-2 hours using iPad, 6 of them (17\%) said the children spend 2-3 hours using iPad, and 10 of them $(29 \%)$ said the children spend more than 4 hours using iPad,

In general, it can be seen that parent opinions are very negative about the iPad. Their attitude may be because they do not know how iPads are used in education; they cannot follow the constant changes, and they have a general distaste for technology. To make their attitude more positive, seminars could be conducted; student activities may be recorded and shown to them.

\section{Conclusion and Suggestions}

There are both benefits and challenges of mobile learning. First of all, using mobile devices in the wild can be highly motivating, increasing children's engagement with their learning. Second, being mobile while learning can encourage children to participate more, facilitating a diversity of key social and cognitive processes. And finally, it offers quite different forms of information flow (ways and means of accessing information) and information management (ways of storing, recording, and reusing information) compared with the conventional use of PCs, enabling children to better integrate their ideas and knowledge with ongoing physical activities (Rogers and Price, 2009)

Students were generally very eager to use the device, and able to pick it up and use it intuitively with little instruction. It was so readily adopted that it was successfully used as a reward.

The device can be used to support engagement and collaboration amongst groups of students working on a project although careful attention needs to be paid to ensuring that students don't dominate the device in a group situation, and to ensure they stay on task and don't get distracted.

It is important to have a good management framework in place, both in the classroom and behind the scenes. Without a proper learning environment, management and facilitation, the device's potential may not be realized. There needs to be a plan for managing things like recharging batteries, application deployment, backups, and protecting, repairing and replacing iPads as needed. In addition, choosing appropriate applications from the large range available can be difficult and thus schools will need to have a process in place to manage this.

It has been seen that teachers' motivation and productivity rise significantly with the assistance of technology. The type of materials used in the classroom can have an important 
impact on whether students can get to like the lessons more, and learn more easily and pleasurably. With the developments in technology, computers have entered almost every student home and they allow them to interact with the colorful animations of computer games. Student interest in lessons increased when they used iPads in their classes. This caused a decrease in student morale when they encountered lessons operated without technology. At this point, using iPad in classes may prove to be a good compensatory agent. In this study, the findings are the result reveals that move parallel to each other the students' opinions.

Educational materials became more versatile and efficient. In classes where iPads were used, a developed learning atmosphere was provided for students with the help of enriched methods and materials. By the integration of the multiple intelligence theorem and learning by living method consistency was established.

If the advantages of iPad usage are to be summarized, all sorts of visual material can be used, and there is easy access to information. Time will be saved and the quality of education increased. By the wide use of visuals in the classroom, students are encouraged to collaborate. Lessons can be made easier and more enjoyable.

As a general evaluation, it can be said that through the integration of smart board and iPad, which can exist in each classroom and create a substructure with audial and visual support, students experience more mobile and different learning methods. In the present research, teachers and students made positive remarks on synchronizing existing smart boards and student iPads through sending lesson presentations, audio logs etc. and thus they can use the technology available in education. For example, students can easily access experimental videos, interactive maps and a variety of visual materials. By carrying their iPads with them, students avoid meaningless material consumption by their not using any sort of paper or other such items.

Teachers stated that most of the students use tablet computers for conducting research online, and prepare presentations to gather together learning materials. Such usage shows that tablet computers provide a wide range of materials which can be used in any lesson.

The pedagogic usage of iPad, and most important of all, the social network establishing tools, or virtual learning settings, should be observed more carefully in the future.

Teachers should be educated about scenarios for evaluation and professional development activities outside the classroom about tablet computer and between teacher-student-parent effectively use communication tools. Thus teachers gain experience with these types of activities should be supported in the long term. A data bank related to Informal learning environments can include activity-based learning and project-based learning outside of the classroom learning as new scenarios.

The addressing of professional development to cover a wider range of issues, in relation to the tablet computer and information technology will support a variety of new applications. In addition, pedagogical training on the use of the iPad and tablet computers in teaching/learning should be provided for all teachers. 
Supporting the devices that is same or similar to the teachers' and has the internet access in school, to students will not only support and improve the education, but also will be useful for teachers by providing various content in order the students to study.

To conclude, the implementation of iPads in the schools is worth the effort as these new large screen mobile devices are leading to innovative new ways for teachers and students to interact with each other and to access information. Devices that can support additional student inquiry and development of online research skills as well as put new digital construction tools in the hands of students, appear to be able to develop new 21 st century skills in learners. Tablets, especially iPad, may in fact be the right combination of mobile tool and connected device for the classroom to meet this kind of need.

\section{References}

An, H. \& Alon, S. (2013). iPad Implementation Models in K-12 School Environments: An Exploratory Case Study. In R. McBride \& M. Searson (Eds.), Proceedings of Society for Information Technology \& Teacher Education International Conference 2013 (pp. 3005-3011). Chesapeake, VA: Association for the Advancement of Computing in Education (AACE). Retrieved August 26, 2015 from http://www.editlib.org/p/48552

Arlı, M. ve Nazik, M. (2001). Bilimsel Araştırmaya Giriş, Gazi Kitabevi, Ankara.

Becta (2004). Technical papers: Tablet PC. Coventry: Becta. Retrieved December 1, 2013 from

http://www.becta.org.uk/subsections/foi/documents/technology_and_education_research /tablet_pc.pdf

Bounds, A. (2013). High-tech well before high school: iPad program expands in Boulder Valley elementary classrooms: McClatchy-Tribune Business News. McClatchy-Tribune Information Services. Washington.

Clarke, B., \& Svanaes, S. (2012). One-to-one Tablets in Secondary Schools: An Evaluation Study. Retrieved August 2, 2015 from http://www.tabletsforschools.co.uk/wp-content/uploads/2012/12/2011-12-Final-Report.p df

Galligan, L., Loch, B., McDonald, C., \& Taylor, J.A. (2010). The use of tablet and related technologies in mathematics teaching. Australian Senior Mathematics Journal, 24(1).

Gawelek, M., Spataro, M., \& Komarny, P. (2011) Mobile Perspectives: on IPads. Why Mobile. Publication of Educause Learning Initiative. Retrieved May 4, 2014 from http://www.educause.edu

Gill, T.G. (2007). Using the Tablet PC for Instruction. Decision Sciences Journal of Innovative Education, 5(1), 183-190. http://dx.doi.org/10.1111/j.1540-4609.2007.00134.x

Henderson, S., \& Yeow, J. (2012). "iPad in Education: A Case Study of iPad Adoption and Use in a Primary School," in System Science (HICSS), 2012 45th Hawaii International 
Conference, 78-87. http://dx.doi.org/10.1109/HICSS.2012.390

Hu, W. (2011). Math That Moves: Schools Embrace the iPad: The New York Times. Retrieved July 14, 2015 from http://www.nytimes.com/2011/01/05/education/05tablets.html?pagewanted=all\&_r=0.

Jones, L. (Jul 16, 2012). Tablets Lead the Charge in Classroom Innovation: Arkansas Business. Arkansas Business. Little Rock. Retrieved May 28, 2013 from http://search.proquest.com/docview/1032529716

Karasar N. (2008). Bilimsel Araştırma Yöntemi, Nobel Yayın Dağıtım,Ankara

Martin, F., \& Ertzberger J. (2013). Here and now mobile learning: An experimental study on the use of mobile technology. Computers \& Education, 68, 76-85. http://dx.doi.org/10.1016/j.compedu.2013.04.021

Rogers, Y., \& Price, S. (2009). Mobile Technology for Children: Designing for Interaction and Learning. Edited by Allison Druin,. Morgan Kaufmann Publishers.

Twining, P., \& Evans, D. (2005). Should there be a future for Tablet PCs in schools? Journal of Interactive Media in Education, 2005(20).

http://dx.doi.org/10.5334/2005-20

Valstad, H. (2011). Introducing The iPad in A Norwegian High School: How Do Students and Teachers React to This Technology. Computer Science. Trondheim, Norway, Norwegian University of Science and Technology.

\section{Copyright Disclaimer}

Copyright for this article is retained by the author(s), with first publication rights granted to the journal.

This is an open-access article distributed under the terms and conditions of the Creative Commons Attribution license (http://creativecommons.org/licenses/by/3.0/). 